\title{
Incidence of JAK2V617F Mutation in Patients with Acute Myeloid Leukemia
}

\author{
Halime OZCAM ${ }^{1}$, Melih AKTAN ${ }^{2}$ \\ ${ }^{1}$ Gaziosmanpaşa University, Faculty of Medicine, Department of Internal Medicine, Tokat \\ ${ }^{2}$ Istanbul University, Istanbul Medical Faculty, Department of Hematology, Istanbul, TURKEY
}

\begin{abstract}
The JAK-STAT is the most important pathway that transmits signals in the cells of normal hematopoiesis and hematologic malignancies. JAK2V617F, which develops in the JH2 region of the JAK2 kinase, is a somatic point mutation. As a result of JAK2V617F mutation, growth of the cells independent of cytokine commences which, in return, produces an increased response to cytokine and causes antiapoptotic effects. Some recent studies have reported that JAK2V617F mutation is seen in 1-10\% of AML patients. Compared to those with de novo AML, JAK2V617F mutation is even higher in patients with AML, which develops secondary to myeloproliferative disorders. In this study the incidence of JAK2V617F mutation in AML patients was examined. The study includes 51 patients with AML. Fourteen percent had secondary AML, 86\% had de novo AML. Twenty-four of the 51 patients were newly diagnosed to have AML and the rest 27 were studied in remission. Genetic analysis of JAK2V617F mutation was performed by using PCR. The results showed that none of our patients had JAK2V617F mutation. This might be attributed to the small number of patients in the study, which develops secondary to myeloproliferative disorders. Another reason could be that JAK2V617F mutation might have disappeared in patients in remission. In conclusion, we thought that it might not be practical to test de novo AML patients for JAK2V617F mutation, and studies on JAK2V617F mutation should be carried out on larger number of patients.
\end{abstract}

Key words: Acute myeloid leukemia, JAK2V617F mutation

\section{ÖZET}

\section{Akut Miyeloid Lösemili Hastalarda JAK2V617F Mutasyonu Sıklığı}

JAK-STAT yolağı normal hematopoez ve hematolojik malignitelerde en önemli bir sinyal ileti sistemidir. JAK2V617F mutasyonu, JAK2 kinazın JH2 bölgesinde gelişen somatik bir nokta mutasyonudur. JAK2V617F mutasyonu sonucunda sitokinden bağımsız olarak büyüme ve sitokine karşı artmış bir yanıt oluşmakta ve antiapoptotik etki gelişmektedir. Son yıllarda yapılan bazı çalışmalarda AML hastalarında \%1-10 arasında JAK2V617F mutasyonun görülebildiği bildirilmektedir. Miyeloproliferatif hastalıklara sekonder gelişen AML hastalarında, de novo AML hastalarına oranla daha yüksek oranlarda JAK2V617F mutasyonu saptanmaktadır. Bu çalışmada AML hastalarındaki JAK2V617F mutasyonu sıkığı araştıııdı. Çalışmaya akut miyeloid lösemi tanısı konulmuş toplam 51 hasta dahil edildi. Hastaların \%14'ü sekonder AML, \%86's ise de novo AML idi. 51 hastanın 24'ü yeni tanı AML idi. 27 hasta ise remisyonda izlenen AML olgularıdır. JAK2V617F mutasyonunun genetik analizi PCR ile Light Cycler cihazında çalışıldı. Çalışmanın sonucunda hastaların hiçbirinde JAK2V617F mutasyonu saptanmadı. Bunun nedenleri olarak hasta sayısının özellikle miyeloproliferatif hastalıklara sekonder AML sayısının az olması ve remisyondaki hastalarda JAK2V617F mutasyonunun kaybolmuş olabileceği düşünüldü. Sonuç olarak de novo AML hastalarında JAK2V617F mutasyonu taramasının pratikte pek yararının olmayacağı ve mutasyon araştırması için daha fazla sayıda hasta içeren çalışmalar yappıması gerektiğini düşünmekteyiz.

Anahtar Kelimeler: Akut miyeloid lösemi, JAK2V617F mutasyonu 


\section{INTRODUCTION}

In the year of 2005, valine- phenylalanine (V617F) somatic point mutation was shown in 617 th position of JAK2. This mutation is commonly seen in chronic acquired myeloproliferative disorders. JAK2V617F mutation is present in almost all of the patients with polycythemia vera (PV). Also, about half of the patients with idiopathic myelofibrosis (IMF) and essential thrombocythemia (ET) carry this mutation. ${ }^{1}$ Spontaneous and constitutive activation was observed in the cells which carry this mutation.

Acute myeloid leukemia (AML) is a clonal disease characterized by the increase of immature myeloid cells in bone marrow and blood. AML can develop de novo or as a secondary. The reasons for the development of secondary AML are as follows: chronic myeloid leukemia, polycythemia vera, myeloproliferative disorders such as idiopathic myelofibrosis and refractory anaemias. ${ }^{2}$ In recent years, some studies suggest that JAK2V617F mutation could be seen in AML patients. ${ }^{3}$ In our study the association between the frequency of JAK2V617F mutation with to treatment response, and survival periods for patients with and without the mutation was investigated.

\section{PATIENTS AND METHODS}

A total of 51 patients which had been diagnosed with acute myeloid leukemia between July 2005 and May 2012 were included in the study. These patients' AML FAB type was detected by morphological characteristics of the bone marrow aspiration smear and immunophenotyping. It was taken into consideration for it to be de novo or secondary AML. The existence of genetic disorders and JAK2V617F mutation was searched. 2 cc venous blood samples were obtained in tubes containing EDTA from the patients. Genomic DNA was isolated from the whole blood samples obtained from the patients as instructed in the kit user guide (Roche Diagnostics, GmbH, Mannheim, Germany). After isolation, DNA concentration was specified with spectrophotometry. The DNA obtained had been stored at $+4^{\circ} \mathrm{C}$ until the study was conducted. The purity of the DNA samples was determined using the OD260 / OD280 ratio.

The PCR mixture prepared to multiply the gene region, which the mutation at JAK2 exon 14 appear, from the DNA samples was distributed on a cold block with each amounting $15 \mu \mathrm{l}$ into the capillary tubes and $5 \mu \mathrm{l}$ (50-100 ng) of the DNA sample was added on top of it.

One negative and one positive control was used for every PCR study. Capillary tubes were centrifuged at $3000 \mathrm{rpm}$. The study was carried out using a Light Cycler 1.5 Real-Time PCR machine (Roche Diagnostic, GmbH, Mannheim, Germany). JAK2V617F mutation was evaluated according to the "melting curve" analysis using Real-Time PCR method.

At the end of the study, the melting peaks observed were analyzed at $640 \mathrm{~nm}$ of wavelength (F2). In accordance with this analysis, while the normal type (JAK2617V) was giving a peak at $64.5^{\circ} \mathrm{C}$, the mutant type (JAK2617F) gave a peak at $57^{\circ} \mathrm{C}$.

The statistical analysis of the data collected in this study was performed using SPPS version 20 software and Excel 2007. The coherence of the variables to the normal distribution was inspected through the Kolmogorov Smirnov/Shapiro-Wilk test. The findings belonging to the data showing normal distribution is given using mean \pm standard deviation; as for the findings belonging to the data not showing normal distribution is given using median (minimum-maximum) values. Survival statistics were calculated using the Kaplan-Meier survival analysis.

\section{RESULTS}

A total of 51 patients which had been diagnosed with acute myeloid leukemia between July 2005 and May 2012 were included in the study and the results are evaluated. The results about the details of patients' clinical and laboratory findings are as given in Table 1. 
Table 1. Patients' clinical and laboratory results

\begin{tabular}{|c|c|}
\hline Age, Mean \pm Standard Deviation & $45 \pm 13$ \\
\hline Gender, & Number (\%) \\
\hline Female & $30(58 \%)$ \\
\hline Male & $21(42 \%)$ \\
\hline \multicolumn{2}{|l|}{ Secondary AML, number (\%) } \\
\hline Present & $7(14 \%)$ \\
\hline Absent & $44(86 \%)$ \\
\hline \multicolumn{2}{|l|}{ Secondary AML, number (\%) } \\
\hline Developed from CML & $1(14 \%)$ \\
\hline Developed from CMML & $1(14 \%)$ \\
\hline Developed from MDS & $4(58 \%)$ \\
\hline Developed after Breast Cancer & $1(14 \%)$ \\
\hline \multicolumn{2}{|l|}{ FAB Type, number (\%) } \\
\hline MO & $5(9,8 \%)$ \\
\hline M0-M1 & $1(2 \%)$ \\
\hline M1 & $3(5.9 \%)$ \\
\hline M1-M2 & $3(5.9 \%)$ \\
\hline M2 & $6(11.8 \%)$ \\
\hline M3 & $17(33.3 \%)$ \\
\hline M4 & $4(7.8 \%)$ \\
\hline M4-Eo & $4(7.8 \%)$ \\
\hline M4-M5 & $3(5.9 \%)$ \\
\hline M5 & $5(9.8 \%)$ \\
\hline \multicolumn{2}{|l|}{ Genetic Abnormalities, number (\%) } \\
\hline Present & $30(58 \%)$ \\
\hline Absent & $21(42 \%)$ \\
\hline
\end{tabular}

Types of genetic abnormalities, number (\%)

45, $X X$, rob $t(13 ; 4)$

$1(3.3 \%)$

$\mathrm{t}(16 ; 16)(\mathrm{p} 13.2 ; \mathrm{Q} 22)$

$1(3.3 \%)$

$\operatorname{inv}(2), \operatorname{inv}(9)$

$1(3.3 \%)$

inv16

$1(3.3 \%)$

Complex Karyotype $3(10 \%)$

$\mathrm{t}(1 ; 12) \mathrm{t} 16 ; 16)$

$\mathrm{t}(15 ; 17)$

$\mathrm{t}(4 ; 16) \mathrm{t}(8 ; 21)$

$16(53,3 \%)$

$1(3.3 \%)$

$1(3.3 \%)$

$1(3.3 \%)$

$1(3.3 \%)$

$1(3.3 \%)$

$1(3.3 \%)$

Trisomy 8

JAK2V617F, number (\%)

Present

$0(0 \%)$

Absent

$51(100 \%)$

\section{DISCUSSION}

Acute myeloid leukemia is a clonal disease characterized by the increase of immature myeloid cells in bone marrow and blood. It could be seen at any age although after 40 years of age the possibility of occurrence increases. ${ }^{4}$ The patients involved in this study aged between 20 through 73 and the average of their ages was detected to be $45 \pm 13$. AML is seen more commonly in males when compared to females. ${ }^{4}$ However, in our study, while $58 \%$ of the patients were female, $42 \%$ of them were male. AML can develop as a secondary or de novo. De novo AML is more commonly seen than the secondary AML. In our study, $14 \%$ of the patients had secondary AML and $86 \%$ of them carried de novo AML.

Hematopoietic cells' proliferation, differentiation and becoming functional are controlled by a set of extracellular molecules which can be classified as cytokines and hormones. In normal hematopoiesis, a set of strictly controlled signal conducting pathways are functionary. It is indispensable for these pathways to function normally for the continuation of the normal hematopoiesis. The disorders that may occur in these pathways can cause the inhibition of apoptosis, uncontrolled reproduction, and malign transformation. JAK-STAT pathway is important in normal hematopoiesis and hematologic malignities. It organizes proliferation, differentiation, and apoptosis of the hematopoietic progenitor and precursors. ${ }^{5}$ It is indicated that JAK-STAT pathway can lead to neoplastic cell growth and trigger malign transformation by the agency of the cytokines in certain situations. Mutations taking place in the protein tyrosine kinase play an important role in this malign transformation.

JAK2V617F mutation is a somatic point mutation taking role in the malign transformation and resulting in the activation of the JAK2 gene. This mutation, identified in the year 2005, is commonly seen in chronic acquired myeloproliferative disorders. ${ }^{6-8}$

After the understating of JAK2V617F mutation's place in myeloproliferative disorders, WHO included JAK2V617F mutation into the 2008 adult myeloproliferative malignity diagnosis and classification criteria. ${ }^{9}$ 
In recent years, some studies suggest that JAK2V617F mutation, between the varying ratios of $1-10 \%$, could be seen in AML patients. ${ }^{9}$

The research of Stavridis et al. suggests that JAK2V617F mutation was detected in $65.3 \%$ of the patients carrying a myeloproliferative disorder and that JAK2V617F mutation could not be found in any of the 39 patients with AML. ${ }^{10}$

JAK2V617F mutation is seen very rarely in de novo AML patients. The research performed by Steensma et al. in 2006 suggests that JAK2V617F mutation was detected in $13(8 \%)$ of the $162 \mathrm{AML}$ patients and that only 3 of these were de novo AML. ${ }^{11}$ Also, only 3 (2.7\%) JAK2V617F mutations were detected in 113 de novo AML patients in the study of Lee et al. in $2006 .^{12}$

After a period of time, 2-5\% of patients with ET and PV and $15-30 \%$ of IMF carrying patients develop transformation to AML. ${ }^{13}$

In our study, $14 \%$ of the patients had secondary AML and $86 \%$ of them carried de novo AML. $14 \%$ of the secondary AML patients developed from CML, another 14\% developed from CMML, 58\% developed from MDS, and 14\% developed after breast cancer. However, JAK2V617F mutation could not be detected in any of the patients. This could be due to the lacking number of patients, especially the number of patients carrying AML secondary to the myeloproliferative disorders.

JAK2 enzyme plays an essential role in normal hematopoiesis and immune response. As the significance of JAK2V617F mutation in myeloproliferative disorders and AML pathogenesis was understood, the molecular goals in AML patients were directed towards developing a JAK2 inhibitor. For that purpose, researches of two new medications, named as INCBo18424 and AZ960, are continuing in AML patients. ${ }^{14,15}$

The result of our study can be interpreted as that the research of JAK2V617F mutation in de novo AML patients, practically, will not be very beneficial.

\section{Acknowledgements}

We would like to thank the staff in the Department of Internal Medicine Hematology of Istanbul University, Istanbul Medical Faculty. This study has been sponsored by the grant provided by Istanbul University Scientific Investigational Projects.

\section{REFERENCES}

1. Levine RL, Belisle C, Wadleigh M. X inactivation based clonality analysis and quantitative JAK2 V617F in PV but not ET/ MMM, and identifies a subset of JAK2 V617F negative ET and MMM patients with clonal hematopoiesis. Blood 107: 4139-4141, 2006.

2. Linet MS, Devesa SS. Epidemiology of leukemia: overview and patterns of occurrence. Ed: Henderson, ES. Lister TA, Greaves MF. Leukemia. Philadelphia, WB Saunders, 2002: 131-135.

3. Jekarl DW, Han SB, Kim M, et al. JAK2 V617F mutation in myelodisplastic syndrome, myelodisplastic syndrome/ myeloproliferative neoplasm, unclassifiable, refractory anemia with ring sideroblasts with thrombocytosis, and acute myeloid leukemia. Korean J Hematol 45: 46-50, 2010.

4. Estey E, Döhne H. Acute myeloid leukemia. Lancet 368: 1894-1907, 2006.

5. Hebenstreit D, Horejs-Hoeck J, Duschl A. JAK/STAT-dependent gene regulation by cytokines. Drug News Perspect 18: 243-249, 2005.

6. Baxter EJ, Scott LM, Campbell PJ, et al. Cancer Genomic Project. Acquired mutation of the tyrosine kinase Jak2 in human myeloproliferative disorders. Lancet 365: 1054-1061, 2005.

7. James C, Ugo V, Le Couedic JP, et al. A unique clonal JAK2 mutation leading to constitutive signaling causes polycythemia vera. Nature 434: 1144-1148, 2005.

8. Lindauer K, Loerting T, Liedl KR, Kroemer RT. Prediction of the structure of human Janus kinase 2 (JAK2) comprising the two carboxyterminal domains reveals a mechanisms for autoregulation. Protein Eng 14: 27-37, 2001.

9. Wadleigh M, Tefferi A. Classification and diagnosis of myeloproliferative neoplasms according to the 2008 World Health Organization criteria. Int J Hematol 91: 174-179, 2010.

10. Panovska-Stavridis I, Cevreska L, Ivanovski $M$, et al. JAK2V617F mutations in myeloid malignancies: single center experience. Prilozi 29: 257-267, 2008. 
11. Steensma DP, McClure RF, Karp JE, et al. JAK2 V617F is a rare finding in de novo acute myeloid leukemia, but STAT3 activation is common and remains unexplained. Leukemia 20: 971-978, 2006.

12. Lee JW, Kim YG, Soung YH, Han KJ, et al. The JAK2 V617F mutation in de novo acute myelogenous leukemias. Oncogene 25: 1434-1436, 2006.

13. Beer PA, Delhommeau F, LeCouedic JP, et al. Two routes to leukemic transformation after a JAK2 mutation positive myeloproliferative neoplasm. Blood 115: 2891-2900, 2010.

14. http://www.empr.com/phase-2 study of the jak2 inhibitor incb018424 in-patients with refractory leukemias including post myeloproliferative disorder mpd acute myeloid leukemia -saml/article/192319 (Access date: 01/18/2013).

15. Ikozoe T, Kojima S, Furihata M, et al. Expression of $\mathrm{p}-\mathrm{JAK} 2$ predicts clinical outcome and is a potential molecular target of acute myelogenous leukemia. Internal Journal of Cancer 129: 2512-2521, 2011.

\section{Correspondence}

Dr. Halime ÖZÇAM

Gaziosmanpașa Üniversitesi Tıp Fakültesi

İç Hastalıkları Anabilim Dalı

Kaleardı Mahallesi Muhittin Fisunoğlu Caddesi

Ali Şevki Erek Yerleșkesi

TOKAT / TURKEY

Tel: (+90.356) 2149444 / 1225

e-mail: halimeozcam@gmail.com 